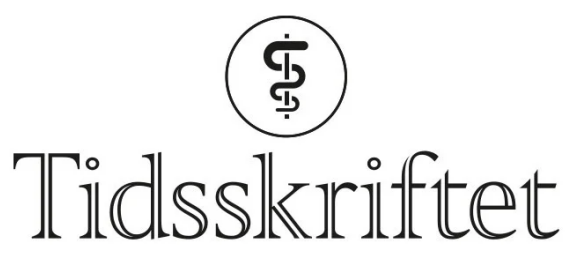

DEN NORSKE LEGEFORENING

\title{
En hyllest til allmennmedisineren
}

ANMELDELSER

\section{MAGNAR J. JOHANSEN}

Universitetssykehuset Nord-Norge

Kreftavdelingen

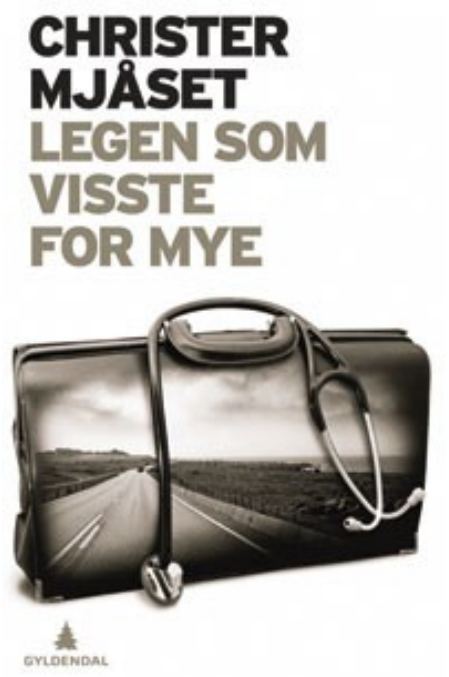

Mjåset, C.

Legen som visste for mye

447 s. Oslo: Gyldendal, 2008. Pris NOK 349

ISBN 978-82-05-37585-7

Hovedpersonen Mads Helmer i hans nye bok startet karrieren på kirurgisk avdeling ved Akershus universitetssykehus. Men etter en fatal operasjon med en ung jentes død som følge forvises han til et liv som allmennlege på Hitra på trøndelagskysten. Der starter et utfordrende liv som lege og privatperson, og da gammeldoktoren dør i en bilulykke, er Mads eneste lege igjen på kontoret. Etter hvert avsløres gammeldoktorens og

lokalsamfunnets hemmeligheter, og Mads tviler på at kollegaens dødsfall var en ulykke. 
Det gis en detaljert beskrivelse av hvordan et lite lokalsamfunns gjennomsiktighet påvirker livet til folkene som bor der. For å overleve som lege her kreves pragmatikk og god legekunst. Livet som allmennpraktiker skildres gjennom mange konsultasjoner på kontoret, på bakeriet og i utallige hjemmebesøk. Her ligger noe av fremstillingens svakhet, nemlig gjentatte skildringer av legejobben uten den naturlige fremdriften som bokens krimmysterium krever. De 447 sidene kunne med fordel vært kuttet ned i antall. Men samtidig gir det et innblikk i en legehverdag som jeg ikke tror er beskrevet skjønnlitterært tidligere. Til tider bikker det over i romantisering, men mange hendelser kan man kjenne seg igjen i. Viktige temaer i legelivet tas opp, blant annet redselen for å gjøre feil. Den detaljerte filmatiske stilen gjør innholdet lettfordøyelig, og som leser utfordres man i liten grad. Uansett får fortellingen etter hvert et godt driv, og man lar seg fornøyelig rive med.

Gammeldoktoren viste seg å være oppslukt av legeromaner. Blant bøkene han etterlot seg, finnes også Legen som visste for mye. Mjåset vil kanskje på denne måten vise at han har skrevet en klassisk legeroman. Men selv om her er dramatikk, romantikk og en følsom og antakelig kjekk, ung lege, gir boken mer. Blant annet en velfortjent hyllest til allmennmedisinen. Og den kan absolutt anbefales.

Publisert: 1. januar 2009. Tidsskr Nor Legeforen. DOI: 10.4045/tidsskr.2009.0525

(C) Tidsskrift for Den norske legeforening 2023. Lastet ned fra tidsskriftet.no 26. april 2023. 